\title{
STATUS OF AGRI-TOURISM BUSINESS IN CENTRAL LUZON, PHILIPPINES: BASIS FOR DEVELOPMENT PLAN
}

\author{
Imee De Guzman Esguerra \\ Bulacan Agricultural State College, Philippines \\ meeic.knight99@gmail.com
}

\begin{abstract}
This study's main objective is to describe farmers' profile that venture into agri-tourism business, analyze the status of their business operation, determine the best practices and problems encountered by agri-tourism businesses in Central Luzon, which served as basis in crafting a development plan. The descriptive research method using a purposive sampling technique was employed in selecting the target respondents who were surveyed and interviewed using two separate sets of modified survey questionnaires. Agritourism businesses were accessible, family-run farms, affiliated with tourism and agriculturerelated organizations, and compliant with required facilities and safety measures. Visitors were from all walks of life and came from within and outside the country. Classes, seminars, workshop, and tours were their top service offerings. Trust and confidence, referral system, hands-on operation, and strict financial monitoring were the identified best practices. At the same time, labour shortage, being still a niche market, price fluctuation, seasonality of farm products and services, insufficient staff skills, and significant capital requirements were the problems in running agri-tourism farms.
\end{abstract}

Keyword: Agri-tourism Business; Development Plan; Farm Tourism

\section{INTRODUCTION}

The Philippines is an agricultural country with rich culture and scenic spots. With thousands of unique islands making up this archipelago, tourists have lots of picturesque places to visit.

The Philippines' tourism industry has been identified as a powerful engine for strong and sustained economic growth (Pilapil-Añasco \& Lizada, 2014). In fact, foreign tourist arrivals to the country continue to increase with 5.9 per cent growth in the first two months of 2019 compared to the same period last year (Rocamora, 2019).

Likewise, agriculture remains a vital part of the country's economy. However, its contribution to the gross domestic product (GDP) has continuously declined for the past several years and even decreased to 10\% last 2017 (Brown, 
2018). The future challenges facing agriculture will require a paradigm shift from a production orientation to a market-centric orientation. One way of doing this is by way of farm diversification through agri-tourism.

Agri-tourism, also called farm tourism as defined by the Department of Tourism (DOT), is an activity done in rural areas, where all stages of agriculture and processing of farm products take place (Lago, 2017). In support of this one of the fastest growing sectors of the economy, R.A.10816 or the Farm Tourism Development Act of 2016 was signed into law which provides guidelines for the promotion and development of farm tourism or agri-tourism in the Philippines.

The Philippine topography is very ideal for agri-tourism (Recio et al., 2014) because of its diverse geographic condition, a relatively English-speaking environment, tropical climate and government initiatives (Spire Research and Consulting, 2013). In fact, Philippine was ranked as one of the top eight agri-tourism destinations in the world last 2012 (Lew, 2012). Southeast Asian Regional Center for Graduate Study \& Research in Agriculture (SEARCA) also stated that the country is now among the world's top agri-tourism destinations, making it par with other agro-tourism sites over the world (Spire Research and Consulting, 2019).

The boost of agri-tourism industry in the Philippines can bring several benefits such as economic growth, social benefits and heritage and cultural conservation (Spire Research and Consulting, 2013). With these numerous benefits of agri-tourism to local residents, different parts of the country are being initiated with this concept (Recio et al., 2014).

Central Luzon, for instance, has a big potential in agri-tourism industry because of its strategic location that offers accessibility for the movement of people, goods and services from the North to Manila. In addition, it remains as the rice granary of the Philippines (Central Luzon still PHL's, 2018).

However, since agri-tourism is just a new venture in the Philippines, this industry's potential benefits have not yet been maximized despite the presence of a number of successful agri-preneurs in Central Luzon. Based on the record of DOT website in 2018, there are only 14 DOT-accredited agri-tourism sites in the region and no farm in Zambales was included in the list.

Only a few researches have been conducted on the area of agri-tourism in the Philippines, and most of the research has been conducted in Region 4A (CALABARZON) as there are a number of pioneers agritourism farms established in the region. Lago (2017) had determined the supply and demand related-factors for agritourism development in Quezon province. Likewise, Recio et al. (2014) have studied the status of prospects of agri-tourism in selected municipalities of the 4th District of Batangas wherein they identified the socio-economic and environmental benefits of agri-tourism in the community. They also found out that studies like this educate people to be more vigilant enough to give importance to agri-tousim in their area.

Unfortunately, based on the best of the researcher's knowledge, no study so far has been conducted on agritourism farms in Central Luzon which could be of great help in promoting this industry in the region. Hence, there is the need for this study in order to identify the profile of farmers who generally go for agri-tourism; analyze the status of their existing business operations; determine their best practices and identify the gaps in their conduct of business which will form as basis for the formulation of development plan to boost the agri-tourism industry. Through 
this study, farmers and agri-preneurs can vividly picture the profile and status of agri-tourism business operations in the region.

\section{METHODOLOGY}

The study employed a mixed method of quantitative-qualitative research using a concurrent nested design. By including both quantitative and qualitative data, the study explained both the process and outcome of agri-tourism business operations through comprehensive observation and analysis of the cases under study.

Quantitative technique was used in gathering data about the profile of agritourism sites, the status of their business operation in terms of organization and management, marketing and production/operation and finance operation, their best practices and problems encountered while qualitative approach was used in gathering their responses during the follow-up interview in order to further clarify and verify their answers to the questionnaires.

Respondents were the farm-owner/operators based on the list provided by the Department of Tourism website in 2018. A purposive sampling technique was employed in selecting the target respondents.

A total of six farm operators and 30 visitors were the respondents who were surveyed and interviewed. Two sets of modified survey questionnaires formulated from the combination of survey questionnaires used by Pinky (2014) in her case study on Agri-tourism in Punjab; Simangan (2012) in his Dissertation on Marketing Strategies of Selected Micro-Manufacturing Enterprises using 4Ps; and Barbieri \& Tew (2009) in their survey on "Preliminary Assessment of Agri-tourism in Missouri" were used in gathering the needed data of the study. These questionnaires were modified based on the statement of the problem of the present study in order to ensure that only the needed data were gathered from the respondents. The questionnaire for farm operators was comprised of four parts. Part I dealt with the profile of the agri-tourism farm such as location, farm ownership, category, farm size, years in operation affiliations and accreditation. Part II included questions regarding the status of agri-tourism business operation in terms of its four core business components including organization and management, marketing, production/operation and finance. Part III and Part IV were open-ended questions asking for the best practices and problems encountered by the farm operators in their agri-tourism business, respectively.

Likewise, the questionnaire for farm visitors was comprised of four parts. Part I dealt with their demographic profile such as age, sex, civil status, educational attainment and primary occupation. Part II included questions regarding their perception on the agri-tourism business practices in terms of marketing, production/operation as these were the areas that they have direct exposure to. Part III and Part IV were open-ended questions asking for what they considered as best practices of the agri-tourism farm they have visited and the problems that they encountered in the areas of marketing and operation/production, respectively.

Frequency count, percentage distribution and rank were the statistical tools used in data analysis. The financial analysis included Return on Investment, Return on Assets and Payback Period. 


\section{RESULTS AND DISCUSSION}

\section{Results}

\section{Profile of Agri-tourism Business in Central Luzon}

Half of the respondent agri-tourism farms are located 30-59 kilometers from the city area while majority $(66.67 \%)$ of them are less than one kilometre near the paved highway. The smallest farm size that can be used to start an agri-tourism farm is one hectare which has expanded to 4.8 hectares progressively as their agritourism operation commenced. Majority are classified as farm resorts while the remaining two other farms operate only as a day farm. The majority are also operating farm business as a family corporation wherein the top management as well as its major personnel are composed of the family members.

Two of the respondent farms were already established as a farm devoted to purely agricultural production as early as 1978 and 1980. However, respondent 1 (2015) and respondent 3 (2008) have already started agri-tourism operation even before the enactment of R.A. 10816 through accepting visitors to their farm for free as their way of promoting agriculture to visitors.

All the respondent farms are affiliated with the Department of Tourism (DOT) and Department of Agriculture-Agricultural Training Institute (DA-ATI) and Central Luzon Farm Tourism Association. Four of the six respondent farms are also TESDA accredited as a training school offering short training courses for National Certification.

\section{Agri-tourism Business Operation in Central Luzon}

a. Organizational and Management

The Organization and Management summarize the information about the business' organizational structure, business members' duties and expertise, as well as their education or qualifications.

Farm operators of all the respondent agri-tourism farms are also its farm owners indicating the hands-on management and commitment of farm owners in running their agritourism business. Four out of the six respondent farm operators are above 50 years old while the remaining two belong to the age bracket of 46-50 years old. Majority are male, married, educated, full-time farmers and self-managed their family-run business.

All the respondent farms are imposing their own policies in their business operation which includes "no smoking"; wearing of safety gears for safety first policy; house rules for those offering accommodation; reservation policy of "no show, considered paid once the slot was reserved"; and swimming attire for those with swimming pools. Majority (66.67\%) of them employs 15 regular employees.

Two out of six farms have 4 to 6 paid family members. In contrast, only one farm has above 10 family members paid for the services they rendered as if they are ordinary employees receiving monthly salary. On the other hand, two farms have 1 to 3 family members who worked in their farms unpaid. Likewise, there are also two farms that used the services of their 4 to 6 family members free of charge, but only share with the annual income of the farm. All of them give bonus to their employees. Majority (66.67\%) of them gives allowances which usually include free meals) while only half of them gives 
$13^{\text {th }}$ month pay. Notably, only one of the respondent farms complies with all the statutory benefits being provided to their employees.

All the respondent farm operators have attended various trainings needed to enhance their skills in managing agritourism farms such as practising agritourism, rendering services and hosting and tour guiding.

\section{b. Marketing Status of Agri-tourism Businesses}

The status of marketing practices of agritourism businesses in Central Luzon is analyzed by determining the presence of business and marketing plans used by agri-tourism operators, describing the nature of their agritourists/visitors, presence of competitors, pricing scheme and promotional strategy used.

Five out of the six farms have written business plans as this is required by DOT which they used as guide in running their business. All of the farms have already entertained different kinds of visitors who have a common goal of learning and experiencing a farmer's daily life in the presence of nature. Consistently, most of the visitors who were interviewed during the data gathering period belong to school groups and organizational groups who are undertaking their short course/training for National Certificate assessment. Majority of whom came from within the region (40\%) and within the province $(33.33 \%)$. Likewise, all the respondent farms stated that they have existing competitors in this industry. However, the other half of the respondent farms admitted that though, they are partners, but the fact that prospective visitors may opt to visit other farms over them still poses a threat of competition.

For general admission or entrance fee, the majority of the farms have a price ranging from P100 to 299. Only two visitors have paid general admission fee of P30 and rented a cottage for P500. The four respondent farm resorts' accommodation price depends on the classification and type of rooms ranging from as low as 500 to as high as above 2500 , but most of them have a room offered for the price of above 2500. All the agritourism farms have a function hall available for rent at the price of 5000 to 10,000 pesos depending on the occasion and seating capacity. However, visitors usually avail agritourism services in package, majority (43\%) of which are TESDA sponsored (P10,000 inclusive of meals, accommodation and other trainings materials for 22 days) while others (20\%) are DA-ATI sponsored (P500-700 inclusive of one-day tour with meals and snacks)

The most common promotion objective of agri-tourism farms is to create product awareness because agritourism is still a new concept and has recently launched a promotional campaign. Almost all (5/6) of them also want to increase their volume of sales and profit as their reason for the conduct of different promotional strategies. In terms of promotional methods, agritourism farms usually promote their farm product and services through the use of social networking sites, listing in specialized directories, printed material, referral system and through an association. Consistently, most of the visitors interviewed heard about the existence of agri-tourism farm through their association, which was tapped by either TESDA or DA-ATI for training sponsorship followed by listing in specialized directory the DOT website. 


\section{c. Operation/Production Status of Agri-tourism Business}

The status of agri-tourism farm operation and production is described by presenting products and services offered, waste disposal, facilities and amenities and process and service operation.

Among the different products and services offered, classes, seminars or workshop and tours are the top service offerings of the six respondent agritourism farms which tied on the top spot followed by u-pick or u-harvest, observation of agricultural processes, petting zoos or farm animal displays and festivals, events and shows. In terms of accommodation and food services, the top four common services that the four farm resorts offer to their visitors were bed and breakfast, farm vacations, campsite and hotel, inn, lodge or resort while the top events that their farm have hosted so far is trainings/workshops/seminars which is usually booked by DA-ATI or TESDA for their sponsored short trainings courses. During an interview, visitors agree with the findings as they said that hotels, inns, lodges or resorts ranked first among the accommodation facilities availed by them specially in the four farm resorts because their NC trainings usually last for several days.

The top two and three accommodation and food services being availed by visitors were bed and breakfast and catering or customized meals as these are usually availed in package by the sponsoring agency. As to the events hosted by farm that the visitors have attended, trainings/workshops/seminars ranked first followed by weddings or private parties and corporate or similar retreats. The result is consistent with the previous tables' findings since most of the visitors were students who are undergoing NC training.

In terms of add-on services, all farms offer welcome drinks to visitors, three have private label products while only one farm (respondent 6) accepts debit or credit card payment mode so far. The same is true with visitors' responses wherein bottled water or soft drinks rank first followed by private label products such as wine and salted eggs as add-on services availed by them. Only three farms have value-added products being offered for sale. Respondent 4 offers salted eggs. Respondent 6 offers salted eggs and pastillas while respondent 3 sells wine made out of bignay fruits which was already approved by the Bureau of Food and Drugs and registered in the Department of Trade and Industry.

All the four respondent farm resorts have accommodation/lodging and restaurants which are additional requirements for them to be accredited as farm resorts. The two accredited day farms do not yet have accommodation/lodging as of now but they have plans to establish such if they will have extra funds. Consistently, all farm operators state that their farms also have all the required sanitation facilities such as wash area, restrooms, garbage cans and garbage disposal/waste management in order to ensure the cleanliness of the farm area.

As to safety and security, safety signages, "off-limit" areas, first aid kit and farm equipment are available in all the respondent farms, which is consistent with visitors' responses. Only one farm has security personnel as farm operators of other farms explained that they do not need such because they feel that their farms are safe and secured. They only request assistance from local police and "barangay tanod" if there are big events hosted in their 
farm. Majority of them (5/6) also have CCTVs installed within their farm premises as form of monitoring and security measures as well. Five out of the six farms have firefighting facilities while the other one already has plan to add such.

Half of the respondent farms are already receiving visitors for 6-9 years already. Two farms receive visitors for more than ten years while the remaining one had just opened his farm to visitors 3-5 years ago. The result indicates that farms were already practicing agritourism and entertaining visitors even before they became accredited by DOT.

As to operating hours, respondent 1 and 6 conduct operation for 24 hours. Respondent 3 and 5 are open for 10 hours to accept visitors (although they offer overnight accommodation) while the two day-farms (respondent 2 and 4) are only open for 8 hours. As expected, since four out of the six respondent farms are farm resorts, majority of the visitors interviewed said that they have stayed for 24 hours or an overnight stay in the farm.

All farm operators stated that their agri-tourism farms have visitors log book which served as database of those who visited their farm in order to secure valuable information of their visitors that can be used in the future which was proven true as all the visitors interviewed have signed a logbook upon their entrance in the farm.

All the respondent agri-tourism farms have owned waste disposal method as they are practicing composting to produce organic fertilizer as part of their advocacy towards organic agriculture. Notably, respondent two has owned Material Recovery Facility (MRF) in his farm as he is recycling the nonbiodegradable wastes such as scrap metals, tin cans and wood which he used as fence in his planting area. This waste disposal method is part of the agricultural practices being taught by farm operators to their visitors in order to promote proper waste management for a healthier environment.

\section{Best Practices of Agri-tourism Business}

Farm owners have identified their perceived best practices in their agritourism business. Being a family-run farm, commitment of farm owners and hands on management to what they are doing are the common best practices of all the six respondent farms in terms of organization and management which is consistent with the best practices identified by the visitors.

Word of mouth/referral system, linkage with government agencies and social media presence are the common best practices that farm operators have identified in their marketing strategy while in terms of operation/production, streamlined chain of command is the identified best practice common to all the respondent farms as these farms are family business.

Good relationship with other farmers in the community is also identified as best practice by four out of six farms because farm operators consider them partners in promoting agritourism concept in the community. Notably, visitors identified that demonstration of good agricultural practices and active involvement of farms in various government activities as other best practices which keep them visiting the farm. 


\section{Problems Encountered by Agri-tourism Business}

Labor shortage or labour competition with other industries is the common problem encountered by farm operators in terms of organization and management. As to marketing status, being still a niche market, price fluctuation of raw materials supply and the seasonal nature of farm products and services were noted problems encountered. Unpopularity of agritourism to mass market is also perceived as a problem by three visitors who stated that they totally have no idea about agritourism if they have not been part of the group of NC trainees. Visitors explained that this could also be due to the difficulty accessing these farms' websites as only two of the respondent farms have functional websites.

In terms of operation/production, insufficient skills of staff were identified by majority (4/6) of the farm owners because they experienced difficulty in recruiting quality staff due to stiff competition with other industries offering higher salary to the applicants. Notably, inaccessibility of the road going to their farm is also identified problem by the farm operators which is consistent with the problem identified by the visitors who noted location and the inaccessibility of public transportation vehicle as problems encountered by them. In addition, visitors' unfavourable weather condition during their tour around the farm also caused difficulty to the them roaming around the farm area.

Unanimously, big capital requirements and big expenditures and operational expenses in running agritourism farms are the identified problems encountered by all the six respondent farms. Surprisingly, two agritourism farms noted that political factor in their location posts additional problem to them because of their bureaucratic process in processing legal documentary requirements.

\section{DISCUSSION \\ 1. Profile of Agri-tourism Business in Central Luzon}

Location of agri-tourism farm may be a consideration for the agritourist in deciding which farm to visit. It is the number one factor critical to success and since agritourism is primarily a subset of tourism, location emerges as the primary factor of success (Comen, 2017). Agri-tourism farms in Central Luzon are accessible to potential visitors but are located farther than what Jiang \& Wang (2018) concluded in their study that agri-tourism location closer to the city (less than $20 \mathrm{~km}$ ) is preferred. Lucha (2015) also found that agri-tourism sites near the metropolitan areas tended to have the highest perceived profitability. Barbieri \& Tew (2010) on the other hand, found that proximity of the farm to highly populated areas is neither an impediment nor an advantage to the number of visitors received.

The size of the business also matters as one can take advantage of economies of scale wherein large farms perform well (Hung et al., 2016) which is contrary to the findings of Schilling et al. (2014) that commercial-scale farms did not increase profits by engaging in agri-tourism. Agri-tourism in Central Luzon has an increasing trend in the farm size from start to present. This indicates that farmers who want to venture into this kind of business can do so if they have at least one 
hectare of farmland. Barbieri \& Tew (2010b) concluded that farm acreage should be considered neither an impediment nor an advantage in agri-tourism development

The ratio on the classification of agri-tourism in the region reflects the ratio of the data on the list provided by DOT as there are more DOT-accredited agritourism farms classified as farm resorts than day farm. This can be due to the reason that farm operators believe in the big potential of agri-tourism business as an additional source of income which motivates them to continue developing their farm and invest more in infrastructure (inclusion of restaurant, accommodation facilities and other farm attractions), thus converting their farm from being classified previously as day farm into farm resort. Farm Tourism Development Act of 2016 (R.A. 10816) describes a day farm as an ideal for day tours/visits usually located near national highways and main business areas while a farm resort is a farm that offer accommodation and dining services, for the purposes of participating in or enjoying interactive on-farm activities and other attractions offered to enrich the tourist's farm life experience.

Bagi and Reeder (2012) found that individual and family-owned farms are more likely to adopt agri-tourism like in the case of agri-tourism farms in the region. They were experienced farmers as they have been actually practising agri-tourism even before the enactment of Farm Tourism Act of 2016 but they are unaware that what they are doing is actually agri-tourism. Barbieri \& Tew (2010)found that farm visitation builds over time which implies that the longer the farm operates the more visitors it receives. Lucha (2015) hypothesized that experienced operators in agriculture and business are more likely to be successful and their businesses more profitable.

A big factor in the agri-tourism business in the region is the linkages to various stakeholders that provide support to the farm owner. Being affiliated with various government agencies is a big advantage as they were prioritized to become venue of various pieces of training from where they generated a big percentage of their income. Lun et al. (2016) also noted that inter-sectoral networks' presence seems to be key success factors to overcome potential obstacles in rural tourism development. Vahauski (2016) also found that networking is needed in engaging profession of farm tourism entrepreneur. Intensive business networking augments overall farm profitability perceptions. Farms with higher number of visitors are more involved in agricultural groups and associations (Barbieri \& Tew, 2010a). Reid (2017) noted that horizontal networking creates efficiencies within a sector like knowledge and cost-sharing, marketing consortia or purchasing linkages. Vertical networks can help to leverage limited resources more effectively.

\section{Agri-tourism Business Operation in Central Luzon Organizational and Management}

Being a family-run business seems to be beneficial to the agri-tourism farms. Farm owners explained that since agriculture is their passion, they made sure that they, themselves together with their family's help, are involved in conceptualizing and designing even the smallest details of their farm. Unfortunately, majority of the 
farm operators are already old age. This can be attributed to the fact that majority of them are retired employees who opted to spend the rest of their lives in simple living managing their own farms. But they are managing their farm with family members' help, which indicates the importance of family members' involvement in running an agri-tourism farm. Page and Connell (2012) as cited in Recio et al. (2014)stated that family labour tends to be the main source of assistance in farm tourism enterprises. The legacy has to be passed on to the young generation who has a big potential to earn more as Barbieri \& Mshenga (2008) found out that farmer age was inversely related to agritourism business performance. Schilling et al. (2014) also found that the younger the farmer-owner, the more profitable is the business. To realize this, there is a need for more comprehensive trainings especially in the field of tourism as most of the trainings undergone by farm operators were agriculture-related.

Agri-tourism farm owners in the region are male-dominated which reflects the case of agriculture in the Philippines. But this is contrary to the findings of McGehee et al. as cited in Delfino (2014) concluded that females had motivation to start agritourism enterprise than males. A big advantage is the fact that agri-tourism operators in the region are educated as education is significant factor in agri-tourism farm performance (Joo et al., 2013). Relevant profession and educational background of entrepreneur as well as enthusiasm are important (Vahauski, 2016). Lago (2017) also noted that the higher the educational attainment of farmers, the more capable they are in supplying agri-tourism products and activities. Reid (2017) further posited that the owner of agritourism could act as educator, provider of safe local food and experiential tourism as agri-tourism is focused on the experience of being on a working farm.

\section{a. Marketing Status of Agri-tourism Businesses}

Toner \& Webster (2011) found in their study that marketing skills are essential to successful recreation-based enterprise which is usually an unfamiliar task for private landowners. Unfortunately, the absence of a concrete business and marketing plans of agri-tourism farms in Central Luzon prevents them from maximizing their business potentials. Barbieri \& Tew (2010) also noted that farms in Missouri operate with no written business or marketing plans. A well-thought of plans (not just plans for the sake of complying with the DOT-requirements), could have enabled the farms by serving as guide in exploring opportunities in this industry.

Visitors of agri-tourism businesses in Central Luzon were basically from all walks of life and came from within and outside the country. Tourists in this type of rural tourism are allowed to visit farms and experience a farmer's daily life (Kunasekaran et al., 2011). According to the farm operators, majority of their visitors are usually students from tertiary level who came in school groups having their educational trip in the farm in order to better appreciate agriculture. In addition, they further explain that bulk of their student-visitors are composed of those undergoing training for $\mathrm{NC}$ assessment from which they actually generate the biggest percentage of their 
farm revenue. The result shows the advantage of being accredited learning sites of TESDA in attracting more agri-tourism visitors and gaining more exposure to wider visitor groups as well

The pricing scheme is considered affordable by the visitors that were interviewed although they do not pay for their stay in the farm as majority of them have availed agri-tourism services paid by TESDA who sponsored their trainings followed by those paid by DA-ATI. Farm owners explained that visitors may opt to pay additional charges depending on the activity that they want to experience in which majority of the farms offer for the price range of 300 to 499 pesos. Expanded, reasonably priced and easily accessible product is a success factor (Vahauski, 2016). Farmers are price makers, not price takers (Reid, 2017).

Farm operators explained that the most effective promotional method is referral system wherein their satisfied previous visitors' testimony of their experience in the farm really brought more visitors in their farm in order to try and experience the same. Notably, there are already two farms that can be accessed through various computer reservation systems such as Traveloka and Tripadvisor, which play a vital role in improving accessibility in the tourism sector. Agri-tourism should focus on tourist experience and create a marketing message based on these experiences to appeal to potential travellers' emotions (Hudson \& Ritchie, 2009). Yeboah et al. (2009) found out that successful case study farmers used a combination of marketing strategies including internet, farmers market, contracts and direct sales to restaurants and grocery stores. Barbieri \& Tew (2010) concluded that farms with greater number of visitors received used more marketing techniques such as personal selling strategies, internet, web page and blogs.

\section{b. Operation/Production Status of Agri-tourism Business}

Lun et al. (2016) noted that creation of quality products and services seem to be fundamental criteria for successful rural development. In the case of agri-tourism farms in Central Luzon, classes, seminars or workshops as most visitors are students who are undergoing $\mathrm{NC}$ training are the top services offered by the farm followed by tours and u-pick or u-harvest. Phillip et al. (2010) noted that products in agri-tourism can include anything from overnight farm stays to educational seminars. Farm operators explained that more products and services will be offered soon as they are still on the process of developing their farm to make it more attractive to visitors. Production of value-added products has a big potential in respondents farms if given support by the concern agencies.

In terms of facilities and amenities, since all the six respondent farms are DOT-accredited as they are all compliant with the minimum required facilities that must be available in an agri-tourism farm. As expected, since four out of the six respondent farms are farm resorts, majority of the visitors interviewed said that they have stayed for 24 hours or an overnight stay on the farm. This indicates that the stay of farm visitors can be maximized if there are accommodation facilities available for visitors' overnight stay as 
visitors said that their purpose of going to the farm aside from learning is to relax in serenity and good scenery. Revenue increases with the number of business days open (Schilling et al., 2014). The qualities offered to the customers that make them feel special are also keys to business success (George \& Rilla, 2011).

All respondent farms also have owned waste disposal system. Farm owners explained that organic fertilizers could be produced from their wastes which are then being applied in their crops in order to produce safer and healthier food for their family and visitors. Likewise, since safety and security become the major consideration of tourists to visit agri-tourism sites (Lago, 2017, farm owners have to assure their visitors that it is safe to stay on their farm. However, assurance of tourists' safe stay in the farm is still questionable as only one of them have security guard so far.

\section{Best Practices of Agri-tourism Business}

Being a family-run farm business was seen as an advantage in terms of organization and management of agritourism business since conflicts gets easily resolved, and employees who are composed of family members have genuine concern for the welfare of the business. The hands-on operation of farm operators who are very responsive to their needs during their stay in the farm was perceived by the visitors as one of their best practices. Having a very knowledgeable farm operator who acted as farm guide is also considered by visitors as best practice because according to them, learning is the primary reason of their visit to agritourism farm. The chain of command is short and simple as the family members can go directly to the farm operators if there are concerns or problems that need immediate actions.

Farm operators further explained that word of mouth or referral system is the most effective promotional strategy in their case as most of their previous visitors told them that they learned about their farm from their friends or family members who have been there before and who shared them their experiences in the farm. This implies the importance of visitor satisfaction with their experience in the farm as word of mouth is very powerful in promoting agri-tourism farms. This is consistent with the findings of George \& Rilla (2011) that word of mouth is the most powerful and inexpensive promotional method. It is the most effective way of promoting agri-tourism (Barbieri \& Mshenga, 2008).

Good relationship with other farmers in the community is also identified as best practice by four out of six farms because farm operators consider them partners in promoting agritourism concept in the community. The same is true with the result of interview conducted by Agritourism Philippines in 2013 from some agritourism operators on what they consider as best management practices for agritourism which includes authentic farm experience, educational experience, customer service, adequate public facilities, safe and accessible environment, community relations and planning for your financial future (www.agmrc.org.) 


\section{Problems Encountered by Agri-tourism Business}

The problems encountered by agri-tourism farms in Central Luzon are consistent with the problems noted by Pinky (2014) which include insufficient fund for publicity; lack of government support, insufficient literature related to agritourism practice and lack of training for agritourism are some of the problems being encountered by farm operators in Punjab. Farm owners claimed that agritourism farms are not suitable for small farmers as of now since venturing in this kind of business requires high initial capital and still needs high working capital to finance its operating expenses.

In addition, labor shortage being experienced by agri-tourism farms in Central Luzon can be attributed to the reason that graduates nowadays prefer working in offices and other business districts than working in the farm away from the luxury and busy life in the cities. Hence, farm owners expressed that they have experienced difficulty in recruiting quality staff. Even worst, those quality staff that they have recruited before are also resigning after few months or years of working in the farm resulting to high employee turn-over.

Farm owners further explained that agritourism industry is still young and they really faced a big burden on how to introduce this concept and promote this new brand of tourism to the mass market in order to increase tourist arrivals/visitors in their farm. However, during off-season, visitors cannot maximize their stay in the farm for they hardly observe actual farm demonstration or harvesting of produce.

Unfortunately, The Manila Times Online in December 2017 reported that agritourism in the Philippines faces a development hurdle because of its noninclusion in the Investment Priorities Plan (IPP) 2017 as well as the lack of financing for cooperatives were identified as the major development gaps that hinder Philippine agritourism development.

\section{Proposed Development Plan}

A development framework for agri-tourism business in Central Luzon has been formulated afterwards based on the findings of the study. The long-term, highlevel goal for agri-tourism development is to boost agri-tourism industry through strengthening agri-tourism businesses in Central Luzon which is linked to four strategic areas of focus. A guiding objective applies to each of the focal areas.

Strategic actions for each of the four focal areas are outlined below. Each strategic action for development plan identifies the key constraints, key strategies, lead stakeholder responsible for implementation, performance indicator, target, means of verification and time frame (see Table 1 to 4 below). 
Table 1. Detailed Development Framework for Focal Area One

Focal Area One- Institutional Development

Objective: Enhanced organizational structure of agri-tourism business

\begin{tabular}{|c|c|c|c|c|c|c|}
\hline $\begin{array}{l}\text { Key } \\
\text { Constraints }\end{array}$ & Key Strategies & $\begin{array}{l}\text { Lead } \\
\text { stakeholder } \\
\text { responsible }\end{array}$ & $\begin{array}{l}\text { Performance } \\
\text { Indicator }\end{array}$ & Target & $\begin{array}{l}\text { Means of } \\
\text { Verification }\end{array}$ & $\begin{array}{l}\text { Time } \\
\text { Frame }\end{array}$ \\
\hline $\begin{array}{l}\text { 1. Employee } \\
\text { turn-over }\end{array}$ & $\begin{array}{l}\text { Offer } \\
\text { competitive } \\
\text { compensation } \\
\text { package and } \\
\text { career growth }\end{array}$ & $\begin{array}{l}\text { Farm } \\
\text { owner }\end{array}$ & $\begin{array}{l}\text { Employee } \\
\text { turnover } \\
\text { rate }\end{array}$ & $\begin{array}{l}\text { Reduce } \\
\text { employee turn- } \\
\text { over rate by } \\
10 \% \text { per year }\end{array}$ & $\begin{array}{l}\text { Employee } \\
\text { records }\end{array}$ & $\begin{array}{l}3-5 \\
\text { years }\end{array}$ \\
\hline $\begin{array}{l}\text { 2. Difficulty } \\
\text { recruiting } \\
\text { quality } \\
\text { staff }\end{array}$ & $\begin{array}{l}\text { Professionalize } \\
\text { agri-tourism } \\
\text { industry }\end{array}$ & $\begin{array}{l}\text { CHED } \\
\text { DA/ATI } \\
\text { DOLE } \\
\text { DOT } \\
\text { Farm } \\
\text { Owner } \\
\text { LGU }\end{array}$ & $\begin{array}{l}\text { Number of } \\
\text { newly hired } \\
\text { quality staff }\end{array}$ & $\begin{array}{l}\text { Increase the } \\
\text { number of } \\
\text { newly hired } \\
\text { qualified } \\
\text { employees by } \\
10 \% \text { per year } \\
\text { (as the need } \\
\text { arises) }\end{array}$ & $\begin{array}{l}\text { List of } \\
\text { employees }\end{array}$ & $\begin{array}{l}2-3 \\
\text { years }\end{array}$ \\
\hline $\begin{array}{l}\text { 3. Lack of } \\
\text { written } \\
\text { rules and } \\
\text { policies }\end{array}$ & $\begin{array}{l}\text { Provide } \\
\text { technical } \\
\text { assistance in } \\
\text { writing farm } \\
\text { rules and } \\
\text { policies }\end{array}$ & $\begin{array}{l}\text { DA-ATI } \\
\text { DOT } \\
\text { Farm } \\
\text { Owner } \\
\text { LGU }\end{array}$ & $\begin{array}{l}\text { Written } \\
\text { rules and } \\
\text { policies }\end{array}$ & $\begin{array}{l}\text { Formulate all } \\
\text { rules and } \\
\text { policies of the } \\
\text { business by } \\
2020\end{array}$ & $\begin{array}{l}\text { Copy of } \\
\text { operation } \\
\text { manual }\end{array}$ & $\begin{array}{l}1-2 \\
\text { years }\end{array}$ \\
\hline
\end{tabular}

Table 2. Detailed Development Framework for Focal Area Two

Focal Area Two- Sector linkages, accreditation and certification

Objective: Increased linkages and gained accreditation from concerned agencies

\begin{tabular}{lllllll}
\hline Key Constraints & Key Strategies & Person/Ag & Performan & Target & Means of Time \\
& & ency & ce & & Verificati Fram \\
& & responsibl & Indicator & on & e \\
& e & & &
\end{tabular}




\begin{tabular}{lllllll}
\hline 1. $\begin{array}{llll}\text { Agri-tourism } \\
\text { farm needs }\end{array}$ & $\begin{array}{l}\text { Provide assistance to } \\
\text { the farm operators in }\end{array}$ & TESDA & TESDA & At least one & Copy of & $3-5$ \\
TESDA and & preparing & Farm & accreditati & $\begin{array}{l}\text { agri-tourism } \\
\text { fen }\end{array}$ & TESDA & years \\
DA-ATI & requirements for & owner & & farm passed & Certificat & \\
$\begin{array}{l}\text { accreditation } \\
\text { to increase }\end{array}$ & TESDA and DA- & LGU & & accreditation & learning \\
$\begin{array}{l}\text { visitors and } \\
\text { augment }\end{array}$ & ATI accreditation & & & per year & sites & \\
income & & & & & & \\
\end{tabular}

\begin{tabular}{|c|c|c|c|c|c|c|}
\hline $\begin{array}{l}\text { 2. Value-added } \\
\text { products } \\
\text { need FDA } \\
\text { and DTI } \\
\text { accreditation } \\
\text { for mass } \\
\text { marketing }\end{array}$ & $\begin{array}{l}\text { Provide assistance to } \\
\text { the farm operators in } \\
\text { preparing } \\
\text { requirements for } \\
\text { Organic } \\
\text { certification, and } \\
\text { FDA and DTI } \\
\text { registration of their } \\
\text { value-added } \\
\text { products }\end{array}$ & $\begin{array}{l}\text { FDA } \\
\text { DTI } \\
\text { LGU } \\
\text { Farm } \\
\text { owner }\end{array}$ & $\begin{array}{l}\text { Organic } \\
\text { certificatio } \\
\mathrm{n} \\
\text { FDA and } \\
\text { DTI } \\
\text { registratio } \\
\mathrm{n}\end{array}$ & $\begin{array}{l}\text { At least one } \\
\text { value-added } \\
\text { product } \\
\text { certified by } \\
\text { FDA and DTI } \\
\text { per year }\end{array}$ & $\begin{array}{l}\text { Copy of } \\
\text { FDA and } \\
\text { DTI } \\
\text { certificat } \\
\text { e }\end{array}$ & $\begin{array}{l}3-5 \\
\text { years }\end{array}$ \\
\hline
\end{tabular}

\begin{tabular}{|c|c|c|c|c|c|c|}
\hline $\begin{array}{l}\text { 3. Limited } \\
\text { linkage with } \\
\text { online travel } \\
\text { search } \\
\text { platform }\end{array}$ & $\begin{array}{l}\text { Provide assistance in } \\
\text { linking agri-tourism } \\
\text { sites with the online } \\
\text { travel search } \\
\text { platforms to increase } \\
\text { exposure and } \\
\text { accessibility }\end{array}$ & $\begin{array}{l}\text { DOT } \\
\text { DA-ATI } \\
\text { Farm } \\
\text { owner } \\
\text { LGU } \\
\text { Travel } \\
\text { agencies }\end{array}$ & $\begin{array}{l}\text { Linkage } \\
\text { with } \\
\text { linkage } \\
\text { with } \\
\text { online } \\
\text { travel } \\
\text { search } \\
\text { platform }\end{array}$ & $\begin{array}{l}\text { At least one } \\
\text { linkage with } \\
\text { online travel } \\
\text { search } \\
\text { platform } \\
\text { established per } \\
\text { year }\end{array}$ & $\begin{array}{l}\text { Presence } \\
\text { in farm } \\
\text { sites in } \\
\text { online } \\
\text { travel } \\
\text { search } \\
\text { platform } \\
\text { online } \\
\text { page }\end{array}$ & $\begin{array}{l}1-2 \\
\text { years }\end{array}$ \\
\hline $\begin{array}{l}\text { 4. Limited } \\
\text { linkages for } \\
\text { market } \\
\text { destination } \\
\text { of value- } \\
\text { added } \\
\text { products }\end{array}$ & $\begin{array}{l}\text { Provide assistance in } \\
\text { establishing market } \\
\text { linkages with } \\
\text { business } \\
\text { establishments } \\
\text { (hotel, restaurants, } \\
\text { etc.) }\end{array}$ & $\begin{array}{l}\text { DTI } \\
\text { LGU } \\
\text { Farm } \\
\text { owner } \\
\text { DOT } \\
\text { DA }\end{array}$ & $\begin{array}{l}\text { Establishe } \\
\mathrm{d} \text { market } \\
\text { linkage }\end{array}$ & $\begin{array}{l}\text { At least one } \\
\text { market linkage } \\
\text { with business } \\
\text { establishment } \\
\text { per year }\end{array}$ & $\begin{array}{l}\text { MOA/M } \\
\text { OU with } \\
\text { business } \\
\text { establish } \\
\text { ment }\end{array}$ & $\begin{array}{l}1-2 \\
\text { years }\end{array}$ \\
\hline
\end{tabular}


Table 3. Detailed Development Framework for Focal Area Three

\begin{tabular}{|c|c|c|c|c|c|c|}
\hline \multicolumn{7}{|c|}{ Focal Area Three- Human Resource Development } \\
\hline \multicolumn{7}{|c|}{ Objective: Enhanced knowledge and skills of agri-tourism operators and employees } \\
\hline Key Constraints & Key Strategies & $\begin{array}{l}\text { Person/Ag } \\
\text { ency } \\
\text { responsibl } \\
\text { e }\end{array}$ & $\begin{array}{l}\text { Performance } \\
\text { Indicator }\end{array}$ & Target & $\begin{array}{l}\text { Means of } \\
\text { Verificatio } \\
n\end{array}$ & $\begin{array}{l}\text { Time } \\
\text { Frame }\end{array}$ \\
\hline $\begin{array}{l}\text { 1. Limited } \\
\text { tourism and } \\
\text { hospitality } \\
\text { management } \\
\text { skills }\end{array}$ & $\begin{array}{l}\text { Provide } \\
\text { trainings on } \\
\text { tourism and } \\
\text { hospitality } \\
\text { management }\end{array}$ & $\begin{array}{l}\text { DA-ATI } \\
\text { CHED/SU } \\
\text { Cs } \\
\text { DOT } \\
\text { LGU }\end{array}$ & $\begin{array}{l}\text { Number of } \\
\text { tourism and } \\
\text { hospitality } \\
\text { management } \\
\text { trainings } \\
\text { conducted }\end{array}$ & $\begin{array}{l}\text { At least one } \\
\text { tourism and } \\
\text { hospitality } \\
\text { management } \\
\text { skills training } \\
\text { conducted per } \\
\text { year }\end{array}$ & $\begin{array}{l}\text { Training } \\
\text { document } \\
\text { ation }\end{array}$ & $\begin{array}{l}1-2 \\
\text { years }\end{array}$ \\
\hline $\begin{array}{l}\text { 2. } \begin{array}{l}\text { Limited } \\
\text { marketing } \\
\text { skills }\end{array} \\
\end{array}$ & $\begin{array}{l}\text { Provide } \\
\text { trainings on } \\
\text { marketing }\end{array}$ & $\begin{array}{l}\text { DA-ATI } \\
\text { CHED/SU } \\
\text { Cs } \\
\text { DOT } \\
\text { LGU } \\
\text { DTI }\end{array}$ & $\begin{array}{l}\text { Number of } \\
\text { marketing } \\
\text { skills trainings } \\
\text { conducted }\end{array}$ & $\begin{array}{l}\text { At least one } \\
\text { marketing } \\
\text { skills training } \\
\text { conducted per } \\
\text { year }\end{array}$ & $\begin{array}{l}\text { Training } \\
\text { document } \\
\text { ation }\end{array}$ & $\begin{array}{l}1-2 \\
\text { years }\end{array}$ \\
\hline $\begin{array}{l}\text { 3. Limited } \\
\text { processing/v } \\
\text { alue adding } \\
\text { skills } \\
\text { (souvenir, } \\
\text { handicraft- } \\
\text { making) }\end{array}$ & $\begin{array}{l}\text { Provide } \\
\text { trainings on } \\
\text { product value- } \\
\text { adding and } \\
\text { handicraft- } \\
\text { making }\end{array}$ & $\begin{array}{l}\text { DA-ATI } \\
\text { CHED/SU } \\
\text { Cs } \\
\text { DOT } \\
\text { LGU } \\
\text { DTI }\end{array}$ & $\begin{array}{l}\text { Number of } \\
\text { product value- } \\
\text { adding and } \\
\text { handicraft- } \\
\text { making } \\
\text { trainings } \\
\text { conducted }\end{array}$ & $\begin{array}{l}\text { At least one } \\
\text { value-adding } \\
\text { skills training } \\
\text { conducted per } \\
\text { year }\end{array}$ & $\begin{array}{l}\text {-Training } \\
\text { document } \\
\text { ation } \\
\text {-Sample } \\
\text { value- } \\
\text { added } \\
\text { products } \\
\text { and } \\
\text { handicraft } \\
\text { s produced }\end{array}$ & $\begin{array}{l}1-2 \\
\text { years }\end{array}$ \\
\hline $\begin{array}{l}\text { 4. Technology } \\
\text { skills } \\
\text { limitation }\end{array}$ & $\begin{array}{l}\text { Provide } \\
\text { technical } \\
\text { intervention on } \\
\text { technology } \\
\text { skills } \\
\text { enhancement }\end{array}$ & $\begin{array}{l}\text { DA-ATI } \\
\text { CHED/SU } \\
\text { Cs } \\
\text { DOT } \\
\text { LGU } \\
\text { DTI }\end{array}$ & $\begin{array}{l}\text { Number of } \\
\text { technology } \\
\text { skills trainings } \\
\text { conducted }\end{array}$ & $\begin{array}{l}\text { At least one } \\
\text { technology } \\
\text { skills training } \\
\text { conducted per } \\
\text { year }\end{array}$ & $\begin{array}{l}\text { Training } \\
\text { document } \\
\text { ation }\end{array}$ & $\begin{array}{l}1-2 \\
\text { years }\end{array}$ \\
\hline
\end{tabular}

Table 4. Detailed Development Framework for Focal Area Four

\begin{tabular}{|c|c|c|c|c|c|c|}
\hline \multicolumn{7}{|c|}{ Focal Area Four- Value chain support } \\
\hline & Objective: Imp & ve value-ch & in support to $\mathrm{b}$ & gri-toul & dustry & \\
\hline $\begin{array}{c}\text { Key } \\
\text { Constraints }\end{array}$ & Key Strategies & $\begin{array}{l}\text { Person/A } \\
\text { gency } \\
\text { responsibl } \\
\mathrm{e}\end{array}$ & $\begin{array}{l}\text { Performance } \\
\text { Indicator }\end{array}$ & Target & $\begin{array}{c}\text { Means of } \\
\text { Verification }\end{array}$ & $\begin{array}{l}\text { Time } \\
\text { Fram } \\
\text { e }\end{array}$ \\
\hline
\end{tabular}




\begin{tabular}{|c|c|c|c|c|c|c|c|}
\hline & $\begin{array}{l}\text { Transp } \\
\text { ort and } \\
\text { infrastr } \\
\text { ucture } \\
\text { constra } \\
\text { ints }\end{array}$ & $\begin{array}{l}\text { Tap } \\
\text { concerned } \\
\text { government } \\
\text { agencies for } \\
\text { transport and } \\
\text { infrastructure } \\
\text { support }\end{array}$ & $\begin{array}{l}\text { DPWH } \\
\text { LGU }\end{array}$ & $\begin{array}{l}\text { - } \\
\text { Constructed } \\
\text { road and } \\
\text { other } \\
\text { infrastructur } \\
\text { e } \\
\text {-Established } \\
\text { partnership } \\
\text { with } \\
\text { transport } \\
\text { group }\end{array}$ & $\begin{array}{l}\text {-Farm to } \\
\text { market road } \\
\text { constructed } \\
\text { and road } \\
\text { signages } \\
\text { posted within } \\
30 \mathrm{kms} \text { away } \\
\text { going to farm } \\
\text { sites } \\
\text {-at least one } \\
\text { partnership } \\
\text { with } \\
\text { transport } \\
\text { group } \\
\text { established }\end{array}$ & $\begin{array}{l}\text { Road and } \\
\text { other } \\
\text { infrastructur } \\
\text { e in use by } \\
\text { the general } \\
\text { public } \\
\text { MOU/MOA }\end{array}$ & $\begin{array}{l}3-5 \\
\text { years }\end{array}$ \\
\hline 2. & $\begin{array}{l}\text { Supply } \\
\text { chain } \\
\text { limitati } \\
\text { on }\end{array}$ & $\begin{array}{l}\text { Provide } \\
\text { assistance in } \\
\text { sourcing out } \\
\text { raw materials } \\
\text { needed in the } \\
\text { agri-tourism } \\
\text { farm } \\
\text { operation }\end{array}$ & $\begin{array}{l}\text { DTI } \\
\text { DA } \\
\text { Farm } \\
\text { owner }\end{array}$ & $\begin{array}{l}\text {-established } \\
\text { linkage with } \\
\text { supplier }\end{array}$ & $\begin{array}{l}\text {-at least one } \\
\text { linkage with } \\
\text { supplier } \\
\text { established }\end{array}$ & $\begin{array}{l}\text { MOU/MOA } \\
\text { Copy of } \\
\text { Contract }\end{array}$ & $\begin{array}{l}1-2 \\
\text { years }\end{array}$ \\
\hline & $\begin{array}{l}\text { Insuffi } \\
\text { cient } \\
\text { marketi } \\
\text { ng } \\
\text { support }\end{array}$ & $\begin{array}{l}\text { - } \\
\text { Collaborative } \\
\text { support in } \\
\text { staging } \\
\text { strong } \\
\text { awareness } \\
\text { campaign } \\
\text { and inclusion } \\
\text { of agri- } \\
\text { tourism in } \\
\text { tourism } \\
\text { package of } \\
\text { LGUs }\end{array}$ & $\begin{array}{l}\text { DTI } \\
\text { LGU } \\
\text { Farm } \\
\text { owner }\end{array}$ & $\begin{array}{l}\text {-Awareness } \\
\text { campaign } \\
\text { conducted } \\
\text {-Tourism } \\
\text { package } \\
\text { launched }\end{array}$ & $\begin{array}{l}\text {-At least one } \\
\text { awareness } \\
\text { campaign } \\
\text { conducted } \\
\text { and one } \\
\text { tourism } \\
\text { package } \\
\text { inclusive of } \\
\text { agri-tourism } \\
\text { launched per } \\
\text { province }\end{array}$ & $\begin{array}{l}\text { - } \\
\text { Documentat } \\
\text { ion of } \\
\text { awareness } \\
\text { campaign } \\
\text {-percentage } \\
\text { increase in } \\
\text { the list of } \\
\text { visitors } \\
\text {-Copy of } \\
\text { tourism } \\
\text { package }\end{array}$ & $\begin{array}{l}2-3 \\
\text { years }\end{array}$ \\
\hline & $\begin{array}{l}\text { Limite } \\
\mathrm{d} \\
\text { financi } \\
\text { al } \\
\text { resourc } \\
\text { es }\end{array}$ & $\begin{array}{l}\text {-provision of } \\
\text { financial } \\
\text { incentive } \\
\text { scheme to } \\
\text { farm } \\
\text { operators }\end{array}$ & $\begin{array}{l}\text { DA } \\
\text { LBP } \\
\text { DBP } \\
\text { LGU } \\
\text { DOT } \\
\text { Farm } \\
\text { owners }\end{array}$ & $\begin{array}{l}\text { Agritourism } \\
\text { financial } \\
\text { incentive } \\
\text { scheme } \\
\text { launched }\end{array}$ & $\begin{array}{l}\text { At least } 20 \% \\
\text { increase in } \\
\text { financial } \\
\text { resources } \\
\text { /fund } \\
\text { sourcing of } \\
\text { agritourism } \\
\text { sites }\end{array}$ & $\begin{array}{l}\text {-Copy of } \\
\text { contract/MO } \\
\text { A/MOU of } \\
\text { financial } \\
\text { incentive } \\
\text { scheme }\end{array}$ & $\begin{array}{l}1-2 \\
\text { years }\end{array}$ \\
\hline
\end{tabular}




\section{CONCLUSION}

Small-scale family-own farms were usually the type of farms that venture into agri-tourism business. There is still so much to be done in terms of organization and management, marketing and production/operation aspects of the agri-tourism farms in order to boost this industry in the region. Support from various stakeholders should be extended to the farm owners in order to maximize the potential of their farm in agri-tourism. The crafted development plan may serve as a reference to DOT and other concerned government agencies in addressing the problems encountered by both farm owners and visitors so as to stimulate the growth of this new industry.

\section{ACKNOWLEDGMENT}

The researcher would like to extend the deepest gratitude to Dr. Richard V. Simangan for his guidance in the conduct of this study as well as to the respondents for sharing valuable information relevant to this study.

\section{REFERENCES}

Barbieri, C., \& Mshenga, P. M. (2008). The Role of the Firm and Owner Characteristics on the Performance of Agritourism Farms. Sociologia Ruralis, 48(2), 166-183. https://doi.org/10.1111/j.1467-9523.2008.00450.x

Barbieri, C., \& Tew, C. (2009). A Preliminary Assessment of Agritourism in Missouri, University of Missouri Department of Parks. Recreation \& Tourism. https://agrimissouri.com/pdf/agritourismsurvey.pdf

Barbieri, C., \& Tew, C. (2010a). Agritourism in Missouri: A Profile of Farms by Visitor Numbers, University of Missouri Department of Parks. Recreation \& Tourism.

https://agrimissouri.com/pdf/MDA_SpecialReport_A_April2010.pdf

Barbieri, C., \& Tew, C. (2010b). The Economic Benefits of Agritourism in Missouri Farms, University of Missouri Department of Parks. Recreation \& Tourism.

https://agrimissouri.com/pdf/MDA_SpecialReport_B_September2010.pdf

Brown. (2018). The Current State, Challenges and Plans to Philippine Agriculture, Food and fertilizer Technology Center for the Asian and Pacific Region. http://ap.fftc.agnet.org/ap_db.php?id=941

Central Luzon still PHL's. (2018). 'rice granary'-and many other things besides.

Comen, T. (2017). Agritourism Stories Critical Success Factors for Agritourism Entrepreneurs. The 2nd International Congress on Marketing, Rural Development, and Sustainable Tourism. 
Delfino, C. (2014). A Case Study on the Apple Hill Grower's Association: An Agritourism Area in Camino, CA [California State University]. https://digitalcommons.calpoly.edu/cgi/viewcontent.cgi?article $=2434 \&$ conte $\mathrm{xt}=$ theses

George, H., \& Rilla, E. (2011). Marketing Strategies for Agritourism Operations. University of California, Agriculture and Natural Resources. UC Peer Reviewed. https://anrcatalog.ucanr.edu/pdf/8444.pdf

Hudson, S., \& Ritchie, J. R. B. (2009). Branding a memorable destination experience. The case of 'Brand Canada.' International Journal of Tourism Research, 11(2), 217-228. https://doi.org/10.1002/jtr.720

Hung, W.-T., Ding, H.-Y., \& Lin, S.-T. (2016). Determinants of performance for agritourism farms: an alternative approach. Current Issues in Tourism, 19(13), 1281-1287.

https://www.tandfonline.com/doi/abs/10.1080/13683500.2015.1037254

Jiang, Y., \& Wang, S. (2018). Spatial distribution Characteristics of Agri-tourism Consumption [Nanjing Agricultural University]. https://www.mdpi.com/2071-1050/10/4/992

Joo, H., Khanal, A. R., \& Mishra, A. K. (2013). Farmers' Participation in Agritourism: Does It Affect the Bottom Line? Agricultural and Resource Economics Review, 42(3), 471-490. https://doi.org/10.1017/S1068280500004949

Kunasekaran, P., Ramachandran, S., Yacob, M. R., \& Shuib, A. (2011). Development of farmers' perception scale on Agrotourism in Cameron highlands, Malaysia. World Applied Sciences Journal, 12(10-18). https://www.researchgate.net/profile/Mohd_Yacob/publication/265755198_ Development_of_Farmers'_Perception_Scale_on_Agro_Tourism_in_Camer on_Highlands_Malaysia_Postgraduate_student_at/links/549400c90cf278af57 31e5ac.pdf

Lago, N. A. (2017). Tourism Demand and Agriculture Supply: Basis for Agritourism Development in Quezon Province. Asia Pacific Journal of Multidisciplinary Research, 5(3).

Lew, J. (2012). Top 8 agritourism destinations in the world. https:/www.mnn.com/lifestyle/eco-tourism/photos/top-8-agritourismdestinations-in-the-world/philippines?fbclid=IwAR39cEAyJbwk8Wa2P7v2a1oBUk4DIv179bLUUbhWi_EZxGjxoFMQYVOIj0

Lucha. (2015). An Overview of Virginia Agritourism: Results From the 2013 Profitability Survey [Virginia Polytechnic Institute and State University]. https://www.pubs.ext.vt.edu/content/dam/pubs_ext_vt_edu/AAEC/AAEC77/AAEC-77-pdf.pdf 
Lun, L. M., Pechlaner, H., \& Volgger, M. (2016). Rural tourism development in mountain regions: identifying success factors, challenges and potentials. Journal of Quality Assurance in Hospitality and Tourism, 17(4), 389-411. http://www.tandfonline.com/10.108008x.2015.1096754

Phillip, S., Hunter, C., \& Blackstock, K. (2010). A typology for defining agritourism. Tourism Management, 31(6), 754- 758.

Pilapil-Añasco, C., \& Lizada, C. (2014). Philippine Tourism: Evolution towards Sustainability. SHS Web of Conferences.

Pinky, S. (2014). Agritourism in Punjab-A case study [Punjab Agricultural University]. http://krishikosh.egranth.ac.in/handle/1/79607

Recio, B. V. L., Ade, K. A. M. De, Esguerra, C. J. M., Mandanas, S. A., Masangkay, J. T., Mendania, J. A., \& Apritado, J. M. (2014). Status and Prospects of Agritourism in Selected Municipalities of the 4th District of Batangas. Asia Pacific Journal of Multidisciplinary Research, 2(4), 64-71. http://www.apjmr.com/wp-content/uploads/2014/08/APJMR-2014-2-105.pdf

Reid, H. (2017). The Representation and Realities of Agri-tourism in essex County, Ontario [University of Guelph]. https://atrium.lib.uoguelph.ca/xmlui/bitstream/handle/10214/11921/Reid_He ather_201710_MA.pdf? sequence $=1$

Rocamora, J. A. L. (2019). Travel, Tourism is PH Largest Sector in 2018: Report. Philippine News Agency. https://www.pna.gov.ph/articles/1079861

Schilling, B., Attavanich, W., \& Jin, Y. (2014). Does Agritourism Enhance Farm Profitability? Journal of Agricultural and Resource Economics, 39, 69-87.

Simangan, R. V. (2012). Marketing Strategies of Selected Micro-Manufacturing Enterprises: Using 4Ps. Nueva Ecija University of Science and Technology.

Spire Research and Consulting. (2013). The rise of agri-tourism in the Philippines. https://www.spireresearch.com/spire-journal/yr2013/q3/the-rise-of-agritourism-in-thephilippines/?fbclid=IwAR2anIjFxVfFeRb2NmCNTz4XFmx1G8QpDrAR0x2 Fq6ZRz8HcFjKsMzYMkrU

Spire Research and Consulting. (2019). The Philippines is now among the world's top agri-tourism destinations. https://www.searca.org/press/the-philippinesis-now-among-the-world-s-top-agri-tourism destinations?fbclid=IwAR0QnqdkMsxpm1kY7yyCNL7EHzA8KYwEEJ9tn m6LGhmKQTgr33ZMQx8Uzs

Toner, M., \& Webster, S. (2011). Agritourism in Gippsland: An Introduction. https://swiftconsortium.org.au/client/en_AU/search/asset/238025 
Vahauski, J. (2016). Success factors in farm touris- Qualitative Study of farm tourism enterprises in Finland. https://www.theseus.fi/bitstream/handle/10024/107648/Success factors in farm

tourism.pdf;jsessionid=5F1B67C54F261B8DD9538248D28BA8BC? sequen $\mathrm{ce}=1$

Yeboah, A. K., Owens, J. P., Bynum, J. S., \& Okafor, R. (2009). Case studies of Successful Small-Scale Farming in North Carolina. Economics Association's 2016 Annual Meeting the Southern Agricultural. https://ageconsearch.umn.edu/record/229824/files/NCAT_Agritourism_Yebo ahK.pdf 